\title{
Sanal Kaytarma ve Demografik Özellikler Açısından Farklılıklar: Otel İşletmelerinde Bir Araştırma
}

\author{
Meaningful Differences between Demographic Features and Cyberloafing: Case in Hotel Businesses
}

\author{
Metin KAPLAN*, Ali Şükrü ÇETINKAYA** \\ *Yrd. Doç. Dr., Nevşehir Hacı Bektaş Üniversitesi, İ.İ.B.F. Turizm İşletmeciliği ve Otelcilik Bölümü, 50300, Nevşehir. \\ E-posta:mkaplan@nevsehir.edu.tr \\ **Yrd. Doç. Dr., Selçuk Üniversitesi, Silifke - Taşucu MYO, Seyahat Turizm ve Eğlence Hizmetleri Bölümü, 33900, Mersin. \\ E-posta: alisukru@selcuk.edu.tr
}

\section{MAKALE BILGILERI}

Makale işlem bilgileri:

Gönderilme tarihi: 2 Temmuz 2013

Birinci değerlendirme: 29 A ğustos 2013

İkinci değerlendirme: 22 Ekim 2013

Kabul: 26 Ekim 2013

\section{Anahtar sözcükler:}

Önemli sanal kaytarma, Önemsiz sanal kaytarma, Sapkın örgütsel davranış.

\section{ARTICLE INFO}

Article history:

Submitted: 2 July 2013

Resubmitted: 29 August 2013

Resubmitted: 22 October 2013

Resubmitted: 26 October 2013

\section{Key words:}

Major cyberloafing, Minor cyberloa-

fing, Deviant organizational behavior.

\section{$\ddot{O Z Z}$}

Bilgisayar ve internet teknolojilerinin otel ișletmelerinde yaygın kullanımı sonucu, çalıșanların sanal kaytarma faaliyetlerinde bulunma eğilimleri de artmaktadır. Çalıșmanın amacı, otel işletmelerinde çalıșanların demografik özellikleri açııından sanal kaytarma faaliyetleri arasındaki farklılıkları ortaya koymaktır. Yazına dayalı geliştirilen anketle Nevşehir yöresindeki dört ve beş yıldızlı otel işletmelerindeki çalışanlara yönelik 278 anket gönderilmiş, 211 geçerli geri dönüș elde edilmiștir. Veri analizleri sonucunda çalıșanların eğitim düzeyi, ișletmedeki konumları ve çalışılan bölümler ile sanal kaytarma faaliyetleri arasında anlamlı farklılıklar olduğu belirlenmiştir. Eğitim düzeyi arttıkça, önemsiz sanal kaytarma faaliyetlerinin de arttığı, üst kademelerde çalışanların alt kademelerde çalışanlara göre daha fazla ciddi sanal kaytarma faaliyetlerinde bulunduğu ve ön bölümlerde çalıșanların arka bölümlerde çalışanlara göre daha fazla önemsiz sanal kaytarma faaliyetlerinde bulunduğu belirlenmiştir.

\section{GiRiş}

Rekabetin yoğun bir şekilde yaşandığı günümüzde, insan kaynaklarının ve teknolojinin etkin bir şekilde kullanılması, örgütsel amaçlara ulaşmada büyük önem arz etmektedir. Emek-yoğun özellik gösteren otel işletmelerinde bilişim teknolojilerinin kullanımı ile daha kısa sürede daha fazla mal

* Bu makale, 21. Ulusal Yönetim ve Organizasyon Kongresi'nde (Dumlupınar Üniversitesi, 30 Mayıs-1 Haziran 2013, Kütahya) sunulan "Demografik Ozellikler ve Orgütlerde Sanal Kaytarma" başlıklı özet bildiriden geliştirilmiştir.

\begin{abstract}
Nowadays businesses, including hotels, are increasingly using and adopting information and communication technology. Technology interaction with hotel staff has potential of personal use of technology and internet (which is cyberloafing activities in hotel industry in terms of demographic features. Self-administered 278 questionnaires were distributed to four and five star hotel employees in Nevşehir region. Results of data analyses, based on 211 valid responses, indicated that there were significant differences between cyberloafing behavior and education level, position in the hotel, and department worked. The study showed that as education level increased, minor to lower level employees; and employees at housekeeping department revealed higher minor cyberloafing activities compared with the other departments.
\end{abstract}

ve hizmet üretilebilmektedir. Bilgisayar ve internet teknolojilerinin otel işletmelerinde yaygın kullanı$\mathrm{ml}$, çalışanların kendi amaçları doğrultusunda bu teknolojileri kullanma, internette gezinme, sosyal medya araçlarını kullanma ihtimalini de beraberinde getirmektedir. Aslında internet kullanımının ve sosyal medyanın takip edilmesinin örgüte sağlayacağı olası yararlar bulunmaktadır. İnternet kullanımının çalışanların bilgiye ulaşarak, örgütün verimliliğine katkı sağlama (Seymour ve Nadesan 2007: 544), stres atma, daha yüksek iş tatmini veya 
yaratıcllik (Vitak vd. 2011: 1752) gibi olumlu yansımaları bulunmaktadır. Buna karşın bilgisayar ve internet teknolojilerinin kişisel amaçlı kullanımı, insan kaynaklarının ve zamanın etkin kullanılmamasina (Lim ve Teo 2005: 1083) ve hatta işletmelerin hukuksal anlamda önemli sorunlar yaşamasına neden olabilmektedir (Kaplan ve Öğ̈̈t 2012: 592).

Yazında sanal kaytarma davranışının öncüllerini belirlemeye yönelik araştırmalar bulunmaktadır (Lim, 2002; Blau vd. 2006; Zoghbi vd. 2006; Zoghbi 2009; Ahmadi vd. 2011; Liberman vd. 2011; Kaplan ve Ögüt 2012, Köse vd. 2012). Ancak çalışanların demografik özellikleri açısından sanal kaytarma faaliyetleri arasında anlamlı farklılıklar olup olmadığını analiz eden sınırlı sayıda araştırma bulunmaktadır.

Yöneticiler, farklı demografik özelliklere sahip çalışanların amaçları ile örgütsel amaçlar arasında amaç birliği sağlayabilmek için çalışanların farkl1lıklarını etkin yönetebilmelidir. Araştırmada, çalışanların demografik özellikleri ile sanal kaytarma faaliyetleri arasındaki ilişkinin belirlenmesi amaçlanmıştır. Bu araştırma, diğer sektörlerden farklı bir kültüre sahip olan ve çıktıların insan performansına dayalı olduğu otel işletmelerinde gerçekleştirilmiştir. Sanal kaytarma üzerine yapılan yazın taramasında sanal kaytarma ile demografik özellikler arasındaki ilişkiyi doğrudan inceleyen sınırlı sayıda araştırmaya rastlanmıştır. Bu bağlamda, Türkiye'de otel işletmelerinde bu konuyu ilk kez ele alan araştırma olması, çalışmanın özgün yönünü ortaya koymaktadır. Çalışmanın, gelecekte sanal kaytarma davranışının öncülleri ve sonuçları üzerinde yoğunlaşacak araştırmacılara yol gösterici olacağı, yöneticilere farklılıkları dikkate alarak çalışanları etkin yönetmede fikirler vereceği ve nihayetinde yazına katkı sağlayacağı düşünülmektedir.

\section{KAVRAMSAL ÇERÇEVE}

Sanal kaytarma, çalışanların çalışma saatleri içerisinde internet, bilgisayar ve akıllı cep telefonu teknolojilerini kişisel amaçları doğrultusunda kullanmaları olarak tanımlanmaktadır (Lim 2002; Phillips ve Reddie 2007; Blanchard ve Henle 2008; Ugrin vd. 2008; Vitak vd. 2011). Özkalp vd. (2012: 22) ise sanal kaytarma kavramını "bilgi ve iletişim teknolojilerinin gerek günlük yaşamda gerekse çalışma yaşamında yoğun bir biçimde kullanımı sonucu çalışanların işten kaytarmak amacıyla zamanını boşa geçirmek veya kendi amaçları doğrultusunda internet, Facebook ve kişisel elektronik posta kullanımlarıyla ortaya çıkan boşta geçen zamanlar" (Önsal, 2012: 241) şeklinde tanımlamışlardır. Sanal kaytarma Türkçe yazında "siber aylaklık" olarak da adlandırılmaktadır (Kalaycı 2010). Sanal kaytarma faaliyeti ile ilgili yazında farklı sınıflamalara rastlamak mümkündür. Andranjan vd. (2004) sanal kaytarmayl; zarar verici veya bozucu sanal kaytarma, yaratıcı ve boş zamanları doldurucu sanal kaytarma ve öğretici sanal kaytarma olmak üzere üç boyutta incelerken (Aktaran: Özkalp vd. 2011), Robinson ve Benett (1995) sanal kaytarmayı önemli ve önemsiz sanal kaytarma şeklinde iki boyutta ele almışlardır. Diğer yandan Lim (2002) sanal kaytarma faaliyetlerini internette gezinti aktiviteleri ve e-posta aktiviteleri şeklinde sınıflandırmayı tercih etmiştir. Benzer şekilde Blau vd. (2006) internette gezinti aktiviteleri, işle ilgili olmayan e-posta aktiviteleri ve etkileşimli sanal kaytarma aktiviteleri şeklinde bir sınıflandırma yapmışlardır. Bu çalışmada, Balanchard ve Henle'nin (2008) sanal kaytarma sınıflandırması esas alınmıştır.

Balanchard ve Henle (2008), bazı davranışların diğer davranışlara oranla daha az kabul edilebilir olduğunu vurgulamaktadırlar. Çalışmalarında sanal kaytarma davranışını önemli (ciddi) ve önemsiz sanal kaytarma faaliyetleri şeklinde iki boyutta incelemişlerdir. Önemsiz sanal kaytarma; işle ilgisi olmayan e-posta gönderme/alma, haber veya spor sitelerini ziyaret etme, finansal sitelere bakma, çevrimiçi alışveriş yapma gibi faaliyetleri içerirken, ciddi sanal kaytarma; yetişkin odaklı siteleri ziyaret etme, sohbet odalarına katılma, bahis/kumar sitelerini ziyaret etme, çevrimiçi oyun oynama, müzik indirme gibi faaliyetleri içermektedir (Balanchard ve Henle 2008; Kalaycı 2010).

Sanal kaytarma davranışı üzerine yazında birçok araştırma bulunmasına karşın sanal kaytarma yapanların ortak özellikleri henüz net bir şekilde ortaya konulamamıştır (Vitak vd. 2011). Diğer bir ifadeyle, hangi özellikteki çalışanın diğer çalışanlara kıyasla sanal kaytarmaya daha yatkın olduğunu belirlemeye yönelik araştırmalarda ortak bir fikir oluşturacak sonuçlar elde edilmemiştir. Garrett ve Danziger (2008) bilgisayar kullanan çalışanlar arasında ülke düzeyinde yaptıkları bir araştırmada mesleki durum, iş yerindeki algılanan otonomi, gelir düzeyi, eğitim düzeyi ve cinsiyet durumunun 
sanal kaytarmanın önemli göstergeleri olduğunu belirlemişlerdir.

Demografik özellikler yazında yer alan sanal kaytarma ile ilgili araştırmalarda ağırlıklı olarak kontrol değişkeni olarak kullanılmıştır. Özkalp vd. (2012), Eskişehir ilinde kamu ve özel sektör çalışanları üzerinde yaptıkları araştırmada; önemsiz sanal kaytarmanın daha sıklıkla var olduğunu, özel sektör çalışanlarının, kamu sektöründe çalışanlara göre daha az sanal kaytarma yaptıklarını, kadınların çalışma saatleri içerisinde erkeklerden daha fazla yazılı görüşme (chat) yaptığını, ayrıca eğitim ve işyeri statülerine göre sanal kaytarma faaliyetleri arasında anlamlı farklılıklar olduğunu, buna karşın medeni durum açısından sanal kaytarma faaliyetleri arasında anlamlı bir farklılık olmadığını ortaya koymuşlardır. Diğer yandan Vitak vd. (2011) sanal kaytarmanın nedenlerini belirlemeye yönelik araştırmalarında cinsiyet, ırk, eğitim, yaş, gelir, işletmedeki konum ve iş türünü, kontrol değişkenleri olarak ele almışlardır. Yazarlar araştırmalarında; sanal kaytarma çeşitliliği bakımından ve bireysel sanal kaytarma davranışı bakımından yaş, ırk, eğitim düzeyi ve cinsiyet ile anlamlı ilişki olduğunu; sanal kaytarma sıklığ zeyi hariç yaş, ırk ve cinsiyet ile anlamlı ilişki olduğunu belirlemişlerdir. Benzer şekilde Liberman vd. (2011), cinsiyet, yaş, milliyet, meslek, görev ve internet kullanma becerisi şeklinde ele aldıkları demografik özellikleri, araştırmalarında kontrol değişkenleri olarak kullanmışlardır. Önceki çalışmalarda, kadınların erkeklere kıyasla daha az internette kaytarma yapma eğiliminde oldukları (Morahan-Martin 2001) ve yapılan kaytarma faaliyeti türleri bakımından ise kadınların erkeklere göre daha fazla elektronik posta alıp/gönderme yoluyla sanal kaytarma faaliyetinde bulunduklarının (Jackson vd. 2001) ortaya konması, cinsiyet farklılı̆̆ının sanal kaytarma ile ilişkili olabileceğini göstermektedir. Gençlerin interneti yaşlılara göre çok kullanma eğiliminde olmaları (Pew Internet and American Life Project 2008) ve sanal kaytarma ihtimallerinin yüksek olması (Morahan-Martin 2001) yaş faktörünü önemli bir değişken durumuna getirmektedir. Hollinger vd. (1992) ve Martin vd. (2010), araştırmalarında çalışma süresinin sanal kaytarmanın bir öncülü olduğunu ve çalışma süresi arttıkça sanal kaytarma davranışının azaldı ğını ortaya koymuşlardir.
Yazında, genellikle cinsiyet, ırk, eğitim, yaş, gelir, işletmedeki konum ve iş türünün sanal kaytarmanın önemli göstergeleri olduğu dile getirilmiş (Jackson vd. 2001; Martin vd. 2010) ve genellikle kontrol değişkenleri olarak ele alınmıştır (Morahan-Martin 2001; Garrett ve Danziger 2008; Liberman vd. 2011; Vitak vd. 2011). Diğer çalışmalardan farklı olarak araştırmanın sorunsalı şudur: "Otel işletmelerinde çalışan personelin demografik özellikleri açısından sanal kaytarma faaliyetleri arasında istatistiksel olarak anlamlı farklılıklar var mıdır?". Bu bağlamda, yazında yapılan çalışmaların da 1şığında, konaklama işletmelerine yönelik olarak aşağıda belirtilen hipotezler ileri sürülmüştür:

$\mathrm{H}_{1}$ : Cinsiyet ile sanal kaytarma arasında anlamlı ilişki vardir.

$\mathrm{H}_{2}$ : Medeni durum ile sanal kaytarma arasında anlamlı ilişki vardır.

$\mathrm{H}_{3}$ : Yaş ile sanal kaytarma arasında anlamlı ilişki vardir.

$\mathrm{H}_{4}$ : Ĕ̈itim durumu ile sanal kaytarma arasında anlamlı ilişki vardır.

$\mathrm{H}_{5}$ : Çalışma süresi ile sanal kaytarma arasında anlamlı ilişki vardır.

$\mathrm{H}_{6}$ : İşletmedeki konum ile sanal kaytarma arasında anlamlı ilişki vardır.

$\mathrm{H}_{7}$ : Çalışılan bölüm ile sanal kaytarma arasında anlamlı ilişki vardır.

\section{YÖNTEM}

Araştırmanın örneklemini Nevşehir ilinde faaliyet gösteren 4 ve 5 yıldızlı otellerde çalışan işgörenler oluşturmaktadır. Örneklem çerçevesini belirlemek için söz konusu otellerin üst düzey yöneticileri ile bireysel görüşmeler yapılmış ve toplam işgören sayısının 993 olduğu tespit edilmiştir. Bölgedeki bir otel yöneticisi anket uygulamasına izin vermediğ $i$ için bu otel araştırmaya dahil edilememiştir. Evrenin 993 olduğu, güven düzeyinin \%95 ve güven aralığının 0,05 olduğu bir kütlede örneklem büyüklügünün yaklaşık 278 (Çıngı 1994: 71) olması gerektiği hesaplanmaktadır. Bu çerçevede basit rasgele örnekleme yöntemi ile 278 anket dağıtılmıştır. Geri dönen anket sayısı 250 'dir. Tamamı veya büyük bir kısmı boş olması nedeniyle bu anketlerden 39'u analizlere dahil edilmemiştir. Analizlere dahil edilen anket sayısı 211 olup, geri dönüş oranı \%76'dır. 
Örneklem sayısının değişken sayısının en az 10 katı olmasının yeterli olacağı yazında belirtilmiştir (Altunış1k vd. 2002: 127). Bu araştırmada veri analizine konu olan 20 farklı değişken söz konusudur. Buradan hareketle mevcut örneklem büyüklügünün, veri analizi yapmak ve sonuçlar üzerinden evrene yönelik genellemeye gitmek için yeterli olduğu söylenebilir. Çalışmada parametrik testler öngörüldüğü için frekans dağılım tabloları incelenmiş ve verilerin normal dağılım gösterdiği görülmüştür.

Araştırmada kullanılan anket, yazında ifade edilmiş, geçerliliği ve güvenirliği ispatlanmış olan ölçeklerden yararlanılarak geliştirilmiştir. Araştırmanın bağımlı değişkeni olan sanal kaytarma için ilk olarak Lim (2002) tarafından geliştirilen ve daha sonra Blanchard ve Henle (2008) tarafından da geliştirilmiş olunan ölçek kullanılmıştır. Tercümeden kaynaklanan olası anlam hatalarını gidermek için alanında uzman sektör çalışan ve yöneticilerine ve akademisyenlere anket formların doldurmaları talep edilmiş elde edilen geribildirimlerle gerekli düzeltmeler yapılarak yüzeysel geçerlilik artırılmaya çalışılmıştır. Türkçeye çevrilmiş hali uyguland1ğ1 için, ölçeğin yapısal geçerliliği açıklayıcı faktör analizi (Altunışık vd. 2002) yapılarak sağlanmıştır.

Sanal kaytarma değişkenleri için 5'li Likert tipi ölçek (1=Hiçbir zaman, 5= Çok sık) kullanılmıştır. Sanal kaytarma değişkeni boyutlarından önemsiz sanal kaytarma boyutunun Cronbach's Alpha değerinin ,90; önemli sanal kaytarma Cronbach's Alpha değerinin ,94 ve sanal kaytarma bağımlı değişkeninin bütününe yönelik Cronbach's Alpha değerinin , 89 olduğu ve bu değerlerin kabul edilebilir düzeyin $(\alpha=, 60)$ oldukça üzerinde olduğu tespit edilmiştir. Araştırmanın bağımsız değişkenleri nominal ve ordinal değişken tiplerinden oluşan demografik özelliklere ilişkin sorulardan oluşmaktadır.

\section{BULGULAR}

Araştırmaya katılanların demografik özelliklerine ilişkin bulguları incelendiğinde (Tablo 1), cevap verenlerin \%64'ünün erkek, \%51'inin evli, \%42'sinin eğitim düzeyinin ortaöğretim, \%34,6'sının çalışma süresinin 1 ile 3 yıl arası, \%59'unun işgören, yaklaşı \% 45 'inin faaliyet bölümlerinde (önbüro, kat hizmetleri ve yiyecek-içecek) çalışanlar olduğu görülmüştür.

Sanal kaytarmanın boyutlarını kontrol etmek ve araştırma örneklemi bağlamında bir farklılık
Tablo 1. Demografik Bulgular $(\mathrm{N}=211)$

\begin{tabular}{|c|c|c|c|}
\hline & Fre & ans & Oran (\%) \\
\hline \multirow[t]{3}{*}{ Cinsiyet } & Erkek & 135 & 64,0 \\
\hline & Kadın & 66 & 31,3 \\
\hline & Cevapsız & 10 & 4,7 \\
\hline \multirow[t]{3}{*}{ Medeni Durum } & Evli & 108 & 51,2 \\
\hline & Bekâr & 86 & 40,8 \\
\hline & Cevapsız & 17 & 8,1 \\
\hline \multirow[t]{10}{*}{ Yaş } & 20 yaş ve altı & 9 & 4,3 \\
\hline & $21-25$ & 54 & 25,6 \\
\hline & $26-30$ & 53 & 25,1 \\
\hline & $31-35$ & 33 & 15,6 \\
\hline & $36-40$ & 21 & 10,0 \\
\hline & $41-45$ & 16 & 7,6 \\
\hline & $46-50$ & 7 & 3,3 \\
\hline & $51-55$ & 8 & 3,8 \\
\hline & 56 yaş ve üzeri & 1 &, 5 \\
\hline & Cevapsız & 9 & 4,3 \\
\hline \multirow[t]{7}{*}{ Eğitim Düzeyi } & İlköğretim & 31 & 14,7 \\
\hline & Ortaöğretim & 89 & 42,2 \\
\hline & Önlisans & 34 & 16,1 \\
\hline & Lisans & 28 & 13,3 \\
\hline & Yüksek Lisans & 9 & 4,3 \\
\hline & Doktora & 7 & 3,3 \\
\hline & Cevapsız & 13 & 6,2 \\
\hline \multirow[t]{6}{*}{ Çalışma Süresi } & 1 yıldan az & 34 & 16,1 \\
\hline & 1-3 yıl & 73 & 34,6 \\
\hline & 4-6 yıl & 42 & 19,9 \\
\hline & $7-9$ yıl & 23 & 10,9 \\
\hline & 10 yıl ve üzeri & 23 & 10,9 \\
\hline & Cevapsız & 16 & 7,6 \\
\hline İşletme İçindeki & Üst Kademe Yönetici & 3 & 1,4 \\
\hline \multirow[t]{5}{*}{ Konum } & Orta Kademe Yönetici & 25 & 11,8 \\
\hline & Alt Kademe Yönetici & 27 & 12,8 \\
\hline & İşgören & 125 & 59,2 \\
\hline & Diğer & 7 & 3,3 \\
\hline & Cevapsız & 24 & 11,4 \\
\hline \multirow[t]{11}{*}{ Çalışılan Bölüm } & Önbüro & 21 & 10,0 \\
\hline & Kat Hizmetleri & 32 & 15,2 \\
\hline & Yiyecek İçecek & 41 & 19,4 \\
\hline & Teknik Servis & 10 & 4,7 \\
\hline & Satış Pazarlama & 12 & 5,7 \\
\hline & İKY & 1 &, 5 \\
\hline & Muhasebe & 8 & 3,8 \\
\hline & Yönetim & 2 & ,9 \\
\hline & Güvenlik & 6 & 2,8 \\
\hline & Memur & 4 & 1,9 \\
\hline & Cevapsız & 74 & 35,1 \\
\hline
\end{tabular}

Cilt $25 \bullet$ Sayı $1 \bullet$ Bahar 2014 
olup olmadığını belirlemek için açıklayıcı faktör analizi yapılmıştır (Tablo 2). Açıklayıcı faktör analizinde örneklemenin sayısının yeterliliğini gösteren Kaiser-Meyer-Olkin (KMO) değerinin ,905 olarak belirlendiği ve bunun da 0,80 'in üzerinde olduğu (Kaiser 1974) görülmüştür. KMO değerinin 0,80 den daha yüksek çıkması, aynı zamanda değişkenlerin birbiri ile ilişkili olduğunu ve ortak faktörleri paylaştığını göstermektedir. Korelasyon matrisinin birim matrise eşit olup olmadığ hipotezini test eden Bartlett's Test of Sphericity sonucu istatistik olarak anlaml1 $\chi^{2}$ sonucu ortaya koymuş $(\chi=1898,682, \mathrm{df}=78, \mathrm{Sig}<000)$ ve faktör analizinin değişkenlere uygulanabileceği görülmüştür (Hair vd. 1998). Değişkenlerin faktör yüklerinin ,53 ile ,78 arasında değişmesi ve ,68 ortalamaya sahip olması; orijinal değerlerin varyansının ortak yüklerle yeterli düzeyde açıklandığını göstermiştir. Sanal kaytarma değişkenine yönelik faktör analizinin uygulanabileceğini belirledikten sonra, varimax döndürme yöntemini esas alan temel eksenler faktör analizi yapılmıştır. Faktör yükü ,50 veya daha yük- sek olanlar (Hair vd. 1998; Kalaycı 2009) bir araya getirilmiştir.

Açıklayıcı faktör analizi, yazında da belirtildiği gibi sanal kaytarma faaliyetlerinin önemsiz sanal kaytarma ve önemli sanal kaytarma faaliyetleri şeklinde iki boyutta incelenebileceğini ortaya koymuştur. Önemsiz sanal kaytarma bileşeni 7,39 değerle en yüksek özdeğere (eigen value) sahiptir ve açılanan toplam varyansın $\% 56,9^{\prime}$ unu temsil etmektedir. Ciddi sanal kaytarma ise 1,50 özdeğere sahiptir ve açıklanan toplam varyansın $\% 11,59^{\prime}$ unu temsil etmektedir. Her iki bileşen toplam varyansın $\% 68,5$ 'ini temsil etmektedir. Açıklayıcı faktör analizinde "bankacılık ya da finansal siteleri ziyaret ederim" ve "işle ilgisi olmayan blokları okurum" maddeleri, sanal kaytarma boyutlarının her ikisi için de yüksek oranlı faktör yüküne sahip oldukları için analize dahil edilmemiştir.

Araştırmanın konusu olan demografik özelliklere ilişkin veriler, nominal veya ordinal veri türündendir. Araştırmada ileri sürülen hipotezleri test edebilmek için nominal veya ordinal veri türünde-

Tablo 2. Açıklayıcı Faktör Analizi

\begin{tabular}{|c|c|c|}
\hline \multirow[t]{2}{*}{ Döndürülmüş Bileşen Matrisia ${ }^{a}$} & \multicolumn{2}{|l|}{ Bileşenler } \\
\hline & $\begin{array}{r}\text { Önemsiz Sanal } \\
\text { Kaytarma }\end{array}$ & $\begin{array}{r}\text { Önemli Sanal } \\
\text { Kaytarma }\end{array}$ \\
\hline İşle ilgili olmayan kişisel e-postalarıma bakarım. & ,868 & \\
\hline Haber sitelerini ziyaret ederim. & ,833 & \\
\hline İşle ilgili olmayan kişisel e-postalar gönderirim. & ,808 & \\
\hline Sosyal paylaşım sitelerini ziyaret ederim (facebook, twitter, vb.) & ,788 & \\
\hline İ̧̧e ilgisi olmayan kişisel bilgilerimi kontrol ederim. & ,679 & \\
\hline Spor sitelerini ziyaret ederim. & ,618 & \\
\hline Alışveriş yaparım. & ,600 & \\
\hline Online açık artırmalara katııırım (ebay, vb). & & ,861 \\
\hline Kişisel web sayfamı düzenlerim. & & ,793 \\
\hline Yetişkin odaklı siteleri ziyaret ederim. & & ,789 \\
\hline Borsa sitelerini ziyaret ederim. & & ,776 \\
\hline Sohbet odalarına katılırım (messanger, vb.). & & ,687 \\
\hline İşle ilgisi olmayan dosyaları (müzik, video, vb.) indiririm. & & ,677 \\
\hline KMO ve Bartlett's Testi Kaiser-Meyer-Olkin Örneklemenin Sayısının Yeterliliği & & ,905 \\
\hline Bartlett's Test of Sphericity & $\begin{array}{l}\text { Yaklaşık X² } \\
\text { df (serbestlik derecesi) } \\
\text { Anlamlılık Değeri }\end{array}$ & $\begin{array}{r}1898,682 \\
78 \\
, 000\end{array}$ \\
\hline
\end{tabular}

Çıkarım yöntemi: Temel Bileşenler Analizi.

Döndürme yöntemi: Kaiser Normalleştirmeli Varimax.

a. Rotasyon 3 tekrarda yakınsadı (ortak noktada benzeşti). 
ki değişkenler, gölge değişkenler (dummy variables) yapısına dönüştürülmüştür. Çalışmanın ileri düzey analizleri, bu değişken yapılar esas alınarak yapılmıştır. Bu tür değişkenler, niteliksel ayrımları içinde barındıran ve nicel bağımlı değişken üzerinde etkili olan değişkenlerdir (Aydın 2005). Bu tür bir niteliksel hali ayrıştırırken 0 ve 1 rakamları kullanılmakta; "1" bir özelliğin varlığını, " 0 " ise o özellik ya da niteliğin yokluğunu simgelemektedir. Bu şekilde gölge değişkenler regresyon modelinde nicel değişkenler gibi kolaylıkla kullanılabilmektedir (Bridge 1971). Yapılan regresyon analizlerinde demografik özelliklerden eğitim, işletmede çalışılan konum ve işletmede çalışılan bölüm bağlamında istatistik bakımından anlamlı ilişkilerin olduğu görülmüştür.

İşgörenlerin eğitim durumları ile sanal kaytarma davranışı arasında nasıl bir ilişki olduğunu belirlemeye yönelik olarak regresyon analizi yapılmıştır. Yapılan analizde ilköğretim düzeyinde eğitime sahip olma ile önemsiz sanal kaytarma arasında istatistik olarak anlamlı ve negatif yönlü bir ilişki olduğu $(\beta=-.32, t(207)=-2,25, p<, 05)$ belirlenmiştir. Düzeltilmiş R kare değeri ,044 olarak hesaplan- miştır $(F(3,97)=4,103, p<, 05)$. Diğer bir ifadeyle, önemsiz sanal kaytarma davranışına ilişkin varyansın \%4,' ${ }^{\prime}$ ü, ilköğretim düzeyinde eğitime sahip olma ile açıklanmaktadır.

İşgörenlerin eğitim durumları ile ciddi sanal kaytarma davranışı arasında nasıl bir ilişki olduğunu belirlemeye yönelik yapılan analizde, regresyon modelinin anlamlı olduğu $\left(R^{2}=, 06, F(3,199)=\right.$ $5,323, p<, 05)$ buna karşın eğitim düzeylerini ifade eden bağımsız değişkenlerin anlamlı bir sonuç üretemediği görülmüştür.

İşletmede çalışılan konum ile sanal kaytarma davranışı arasında nasıl bir ilişki olduğunu belirlemeye yönelik olarak regresyon analizi yapılmıştır. Yapılan analizde alt yönetim düzeyinde $(\beta=-.192$, $\mathrm{t}(207)=-2,04, \mathrm{p}<, 05)$ ve işgören düzeyinde $(\beta=$ $-.276, \mathrm{t}(207)=-2,602, \mathrm{p}<, 05)$ bulunma ile önemsiz sanal kaytarma arasında istatistik olarak anlamlı ve negatif yönlü bir ilişki olduğu belirlenmiştir. Düzeltilmiş $\mathrm{R}$ kare değeri ,022 olarak hesaplanmıştır $(\mathrm{F}(3,197)=2,485, \mathrm{p}<, 05)$. Diğer bir ifadeyle, önemsiz sanal kaytarma davranışına ilişkin varyansın $\% 2,2$ 'si, alt yönetim ve işgören düzeyinde bulunma ile açıklanmaktadır. Buna karşın, çalışılan konum

Tablo 3. Hipotezlerin Desteklenme Durumu

\begin{tabular}{|c|c|c|c|c|}
\hline \multicolumn{5}{|c|}{ Anlamlı İlişki } \\
\hline Demografik Özellik & Gölge Değişken & $\begin{array}{l}\text { Önemsiz Sanal } \\
\text { Kaytarma }\end{array}$ & $\begin{array}{l}\text { Önemli Sanal } \\
\text { Kaytarma }\end{array}$ & Hipotez \\
\hline Cinsiyet & $\begin{array}{l}\text { Erkek } \\
\text { Bayan }\end{array}$ & $\begin{array}{l}\text { yok } \\
\text { yok }\end{array}$ & $\begin{array}{l}\text { yok } \\
\text { yok }\end{array}$ & H1 Desteklenmedi \\
\hline Medeni Durum & $\begin{array}{l}\text { Evli } \\
\text { Bekâr }\end{array}$ & $\begin{array}{l}\text { yok } \\
\text { yok }\end{array}$ & $\begin{array}{l}\text { yok } \\
\text { yok }\end{array}$ & H2 Desteklenmedi \\
\hline Yaş & $\begin{array}{l}\text { Orta Yaş } \\
\text { Genç }\end{array}$ & $\begin{array}{l}\text { yok } \\
\text { yok }\end{array}$ & $\begin{array}{l}\text { yok } \\
\text { yok }\end{array}$ & H3 Desteklenmedi \\
\hline Eğitim & $\begin{array}{l}\text { İlköğretim } \\
\text { Lise } \\
\text { Üniversite }\end{array}$ & $\begin{array}{l}\text { var } \\
\text { var } \\
\text { yok }\end{array}$ & $\begin{array}{l}\text { var } \\
\text { var } \\
\text { var }\end{array}$ & H4 Desteklendi \\
\hline Çalışma Süresi & $\begin{array}{l}1 \text { yıldan az } \\
1-3 \text { yıl } \\
4-6 \text { yıl } \\
7-9 \text { yıl } \\
10 \text { yıl üzeri }\end{array}$ & $\begin{array}{l}\text { yok } \\
\text { yok } \\
\text { yok } \\
\text { yok } \\
\text { yok }\end{array}$ & $\begin{array}{l}\text { yok } \\
\text { yok } \\
\text { yok } \\
\text { yok } \\
\text { yok }\end{array}$ & H5 Desteklenmedi \\
\hline \multirow[t]{2}{*}{ Çalışılan Konum } & Orta ve Üst yönetim & yok & yok & $\begin{array}{l}\text { H6 Orta ve üst yönetim düzeyleri bakımından } \\
\text { desteklenmedi. }\end{array}$ \\
\hline & $\begin{array}{l}\text { Alt yönetim } \\
\text { İsgören }\end{array}$ & $\begin{array}{l}\text { var } \\
\text { var }\end{array}$ & $\begin{array}{l}\text { var } \\
\text { var }\end{array}$ & H6 diğer düzeyler bakımından desteklendi. \\
\hline Bölüm & $\begin{array}{l}\text { Kat Hizmetleri } \\
\text { Önbüro } \\
\text { Yiyecek İçecek } \\
\text { Diğer Bölümler }\end{array}$ & $\begin{array}{l}\text { var } \\
\text { yok } \\
\text { yok } \\
\text { yok }\end{array}$ & $\begin{array}{l}\text { yok } \\
\text { yok } \\
\text { yok } \\
\text { yok }\end{array}$ & $\begin{array}{l}\text { H7 Kat Hizmetleri bölümü açısından desteklendi } \\
\text { H7 diğer bölümler açısından desteklenmedi }\end{array}$ \\
\hline
\end{tabular}


düzeyleri ile ciddi sanal kaytarma davranışı arasında anlamlı ilişki tespit edilememiştir.

İşletmede çalışılan bölüm ile sanal kaytarma davranışı arasındaki ilişkiyi belirlemek için regresyon analizi yapılmıştır. Yapılan analizde kat hizmetleri çalışanları ile önemsiz sanal kaytarma arasında, istatistik olarak anlamlı ve negatif yönlü bir ilişki olduğu belirlenmiş̧tir $(\beta=-.303, \mathrm{t}(206)=-4,035, \mathrm{p}<$ .001). Düzeltilmiş R kare değeri ,073 olarak hesaplanmıştır $(\mathrm{F}(4,196)=4,914, \mathrm{p}<.05)$. Diğer bir ifadeyle, önemsiz sanal kaytarma davranışına ilişkin varyansın \%7,3'ü kat hizmetleri bölümü çalışanları ile açıklanmaktadır. Diğer taraftan, çalışılan bölüm ile ciddi sanal kaytarma davranışı arasında anlamlı ilişki tespit edilememiştir.

Yapılan analizler sonucunda ileri sürülen hipotezlerin desteklenme durumu Tablo 3'te topluca belirtilmiştir.

\section{SONUÇ VE ÖNERILER}

Bu çalışmada Nevşehir ilindeki 4 ve 5 yıldızlı otel işletmelerinde çalışanların demografik özellikleri açısından sanal kaytarma faaliyetleri arasında anlamlı farklılıklar olup olmadığı, anket yöntemi ile oluşturulan veri setinden hareketle analiz edilmiştir.

Veri analizleri sonucunda çalışanların eğitim düzeyi, işletmedeki konumları ve çalışılan bölümler ile sanal kaytarma faaliyetleri arasında anlam11 farklılıklar olduğu belirlenmiştir. Eğitim düzeyi azaldıkça önemsiz sanal kaytarma faaliyetlerinin arttığı, eğitim düzeyinin her seviyesinde ciddi sanal kaytarmanın negatif yönlü ilişkide olduğu, üst kademelerde çalışanların alt kademelerde çalışanlara göre daha fazla önemsiz sanal kaytarma faaliyetlerinde bulunduğu ve kat hizmetlerinde çalışanların diğer bölümlerde çalışanlara göre daha fazla önemsiz sanal kaytarma faaliyetlerinde bulunduğu belirlenmiştir. Otel işletmelerinde farklı konum ve farklı bölümlerde çalışanların doğrudan internete erişim olanaklarının farklı olmasının, bu sonucun çıkmasında etkili olduğu ifade edilebilir. Yazında demografik özelliklerin sanal kaytarma araştırmalarında ağırlıklı olarak kontrol değişkenleri olarak ele alındığı görülmüştür. Özkalp vd. (2012) yaptıkları araştırmada; önemsiz sanal kaytarmanın daha sıklıkla var olduğunu, özel sektör çalışanlarının kamu sektöründe çalışanlara göre daha az sanal kaytarma yaptıklarını, kadınların çalışma saatleri içerisinde erkeklerden daha fazla yazılı görüşme (chat) yaptığını, ayrıca eğitim ve işyeri statülerine göre sanal kaytarma faaliyetleri arasında anlamlı farklılıklar olduğunu, buna karşın medeni durum açısından sanal kaytarma faaliyetleri arasında anlamlı bir farklılık olmadığını ortaya koymuşlardır. Medeni durum açısından sanal kaytarma faaliyetleri arasında farklılığın çıkmaması, eğitim düzeyi açısından anlamlı farklılıkların çıkması bulguları, bu araştırma sonuçları ile benzerlik göstermektedir. Vitak vd. (2011) araştırmalarında, sanal kaytarma çeşitliliği ve bireysel sanal kaytarma davranışı bakımından yaş, rrk, eğitim düzeyi ve cinsiyet ile anlamlı ilişki; sanal kaytarma sıklığı bakımından ise eğitim düzeyi hariç yaş, ırk ve cinsiyet ile anlamlı ilişki olduğunu belirlemişlerdir. Sanal kaytarma çeşitliliği bağlamında, eğitim düzeyi değişkeni açısından bu araştırma Vitak vd.'nin (2011) araştırma sonuçları ile kısmen benzerlik göstermektedir. Morahan-Martin'in (2001) araştırma sonuçlarına göre; kadınların erkeklere kıyasla daha az internette kaytarma yapma eğiliminde olduklarının ve yapılan kaytarma faaliyeti türleri bakımından kadınların erkeklerden farklı türde sanal kaytarma faaliyetinde bulunduklarının (Jackson vd. 2001) ortaya konması, cinsiyet farklılığının sanal kaytarma ile ilişkili olabileceğini göstermektedir. Gençlerin interneti yaşlılara göre çok kullanma eğiliminde olmaları (Pew Internet ve American Life Project 2008) ve sanal kaytarma ihtimallerinin yüksek olması (Morahan-Martin, 2001) yaş faktörünü önemli bir değişken durumuna getirmektedir. İşletmede uzun yıllar çalışmış olanlar, işyerinde daha az sanal kaytarma yapma eğiliminde olmaktadırlar (Hollinger vd. 1992; Martin vd. 2010). Ancak bu araştırmada cinsiyet, yaş ve çalışma süresi değişkenleri ile sanal kaytarma faaliyetleri arasında anlamlı bir ilişki tespit edilememiştir. Bu bağlamda bu araştırma Morahan-Martin (2001), Jackson vd. (2001), Hollinger vd. (1992) ve Martin vd. (2010) araştırma sonuçları ile farklılık göstermektedir. Bu farklılığın araştırmaların farklı sektörlerde ve farklı kültürlerde yapılmış olmasından kaynaklandığı söylenebilir.

Günümüzde bilişim teknolojileri ve internet kullanımı, konaklama işletmeleri dahil her örgüt için kaçınılmazdır. Teknoloji kullanımı beraberinde bunu kullanan işgörenlerin zaman zaman iş amaçları dışında bunları kullanabilmesine de olanak sağlamaktadır. Örgütlerde kullanılan bilgisayar, internet, internet erişimli cep telefonları vb. araçlar, ör- 
gütleri içinde bulundukları çevreler ile etkileşimli hale getirmekte, örgütleri organik yapıda olmaya zorlamaktadir.

Bilgisayar ve internet kullanımının söz konusu olduğu örgütlerde çalışanların sanal kaytarma faaliyetlerinde bulunması hemen hemen kaçınılmazdır. Çalışanların sanal kaytarma bağlamında hatalı davranışlarını kontrol edebilme noktasında yazında iki temel strateji önerilmektedir (Özler ve Polat 2012: 11-12): İçsel yönlü oto kontrol ve dişsal yönlü zorlayıcı stratejiler. Oto kontrol yaklaşımı, bir bireyin içinden gelerek kurallara uymasına odaklanırken; zorlayıcı stratejilerde çalışanların davranışları çevrelerindeki dışsal koşullar tarafından yönlendirilir. Zorlayıcı stratejiler, çalışanların bir kararın fayda ve maliyetlerini karşılaştırarak rasyonel bir şekilde davranmaları ile ilişkilidir.

Günümüz örgütlerinde sanal kaytarma gerçeği bilincinden hareketle çalışanlar yönlendirilerek bu davranış örgüt için avantaja dönüştürülebilir. Örneğin, çalışanlar bu tür davranışlarda bulundukları süre içinde müşterilerle etkileşimli iletişime geçerek geribildirim alabilir; işletme çevresinde ortaya çıkan olası fırsat ve tehditlerden hızlı haberdar olabilir; işletmenin tanıtım, pazarlama ve halkla ilişkiler faaliyetlerine katkı sağlayabilir; işgücü piyasasında nitelikli insan kaynakları edinilebilir; maliyet avantajlarından haberdar olarak ürün tedarikinde işletmenin maliyet avantajı elde etmesine katkı sağlayabilir.

Yukarıda sıralanan olası yararlardan faydalanabilmek için sanal kaytarmanın örgütte bilinçli yapılmasını sağlamak, yöneticiler için bir alternatif olarak görülmektedir. Bunun için örgütte köklü yapısal ve anlayış değişikliğine gidilmesi gerekebilir. Bu değişiklik ise düzenli ve planlı verilecek eğitim ve bilinçlendirme faaliyetleri, çalışanlar ile işverenler arasında açı bir iletişim sisteminin kurulması, bilgisayar kullanım politikaları geliştirmek ve elektronik kontrol sistemleri ile sağlanabilir.

Araştırma, konaklama işletmeleri ile sınırlıdır. Farklı sektörden farklı hedef gruplara yönelik yapılacak araştırmalar örgütlerde sanal kaytarma gerçeğini daha geniş yelpazeden görme olanağ sağlayacaktır. Araştırma, demografik özellikler esas alınarak yürütülmüştür. Sanal kaytarma olgusu, işletme yönetim ve organizasyonunda farklı boyutlar ve değişkenler de dikkate alınarak yürütülebilir.

\section{KAYNAKÇA}

Ahmadi, H., Bagheri, F., Ebrahimi, S.A., Rokni, M.A.N., ve Kahrer, M.S. (2011). Deviant Work Behavior: Explaining Relationship between Organizational Justice and CyberLoafing as a Deviant Work Behavior, American Journal of Science Research, 24: 103-116.

Altunışık, R., Coşkun, R., Bayraktaroğlu S. ve Yıldırım E. (2002). Sosyal Bilimlerde AraştırmaYöntemleri. Adapazarı: Sakarya Kitabevi.

Aydın, N. (2005). Gölge Değişkenlerin Kullanımı ve Çeşitli Uygulamalar (Basılmamış Yüksek Lisans Tezi). İstanbul: İstanbul Üniversitesi Sosyal Bilimler Enstitüsü Ekonometri Anabilim Dalı.

Balanchard, A. L. ve Henle, C. A. (2008). Correlates of Different Forms of Cyberloafing: The Role of Norms and External Locus of Control, Computers in Human Behavior, 24: 1067-1084.

Blau, G., Yang, Y. ve Ward-Cook, K. (2006). Testing a Measure of Cyberloafing, Journal of Allied Health, 35 (1): 9-17.

Bridge, J. I. (1971). Aplied Econometrics. Amsterdam: NorthHolland Publising Company.

Çıngı, H. (1994). Örnekleme Kuramı. Hacettepe Üniversitesi Fen Fakültesi Yayınları Ders Kitapları Dizisi 20. Beytepe/Ankara: H.Ü. Fen Fakültesi Basımevi.

Garrett, R. K., ve Danziger, J. N. (2008). On Cyberslacking: Workplace Status and Personal Internet Use at Work, CyberPsychology \& Behavior, 11: 287-292.

Hair, J.F., Anderson, R.E., Tatham, R.L. ve Black, W.C. (1998). Multivariate Data Analysis. New Jersey: Prentice Hall.

Hollinger, R. C., Slora, K. B. ve Terris, W. (1992). Deviance in the Fast-Food Restaurant: Correlates of Employee Theft, Altruism, and Counterproductivity, Deviant Behavior, 13: 155-184.

Jackson, L. A., Ervin, K. S., Gardner, P. D. ve Schmitt, N. (2001). Gender and the Internet: Women Communicating and Men Searching, Sex Roles, 44: 363-379.

Kaiser, H.F. (1974). An Index of Factorial Simplicity, Psychometrika, 39 (1): 31-36.

Kalaycı, Ş. (2009). SPSS Uygulamalı Çok Değişkenli İstatistik Teknikleri. Ankara: Asil Yayın Dağıtım.

Kalaycı, E. (2010). Üniversite Öğrencilerinin Siber Aylaklık Davranışları ile Öz Düzenleme Stratejileri Arasındaki İlişkinin İncelenmesi (Basılmamış Yüksek Lisans Tezi). Ankara: Hacettepe Üniversitesi, Bilgisayar ve Öğretim Teknolojileri Anabilim Dalı.

Kaplan, M. ve Öğüt, A. (2012). Algılanan Örgütsel Adalet ile Sanal Kaytarma Arasındaki İlişkinin Analizi: Hastane Çalışanları Örneği, 20. Ulusal Yönetim ve Organizasyon Kongresi Bildiriler Kitabı, İzmir (24-26 May1s): 592-596.

Köse, S., Oral, L. ve Türesin, H. (2012). İş Yaşamında Sosyal Kolaylaştırma Kavramı ve Sanal Kaytarma ile İlişkisi: Araştırma Görevlileri Üzerinde Bir Araştırma, Sosyal ve Beşeri Bilimler Dergisi, 4 (1): 287-295.

Liberman, B., Seidman, G., McKenna, K. ve Buffardi, L. (2011). Employee Job Attitudes and Organizational Characteristics as Predictors of Cyberloafing, Computers in Human Behavior, 27 (6): 2192-2199

Lim, V.K.G ve Teo, T.S.H. (2005). Prevalence, Perceived Seriousness, Justification and Regulation of Cyberloafing in Singapore, Information \& Management, 42: 1081-1093.

Lim, V.K.G. (2002). The IT Way of Loafing on the Job: Cyberloafing, Neutralizing and Organizational Justice, Journal of Organizational Behavior, 23: 675-694. 
Martin, L. E., Brock, M. E., Buckley, M. R., ve Ketchen, D. J. (2010). Time Banditry: Examining the Purloining of Time in Organizations, Human Resource Management Review, 20: 26-34.

Morahan-Martin, J. (2001). Caught in the Web: Research and Criticism of Internet Abuse with Application to College Students. İçinde C. R. Wolfe (Ed.), Learning and teaching on the World Wide Web (ss. 191-219). San Diego, CA: Academic Press.

Önsal, N. (2012). Endüstri İlişkileri Sözlü̈̆ü. Türkiye İşçi Sendikaları Konfederasyonu. Ankara: Aydoğdu Ofset.

Özkalp, E., Aydın, U. ve Tekeli, S. (2012). Sapkın Örgütsel Davranışlar ve Çalışma Yaşamında Yeni Bir Olgu: Sanal Kaytarma (Cyberloafing) ve İş İlişkilerine Etkileri, Çimento Iş̧veren, 26 (2): 18-33.

Özkalp, E., Aydın, U. ve Tekeli, S. (2011). Sapkın Örgütsel Davranışlar ve Çalışma Yaşamında Yeni Bir Olgu: Sanal Kaytarma (Cyberloafing) ve İş İlişkilerine Etkileri, 19. Ulusal Yönetim ve Organizasyon Kongresi Bildiriler Kitabı, Çanakkale (26-28 May1s): 465-470.

Özler, D.E. ve Polat, G. (2012). Cyberloafing Phenomen in Organizations: Determinants and Impacts, International Journal of eBusiness and eGovernment Studies, 4 (2): 1-15.

Pew Internet ve American Life Project (2008). http://www.pewinternet.org/index.aspx, Erişim tarihi: 01.07.2013.
Phillips, J. G. ve Reddie, L. (2007). Decisional Style and SelfReported Email Use in The Workplace, Computers in Human Behavior, 23 (5): 2414-2428.

Robinson, S. L. ve Bennett, R. J. (1995). A Typology of Deviant Workplace Behaviors: A Multidimensional Scalling Study, Academy of Management Journal, 38 (2): 555-572.

Seymour, L. ve Nadasen, K. (2007). Web Access for IT Staff: A Developing World Perspective on Web Abuse, The Electronic Library, 25 (5): 543-557.

Ugrin, J.C., Pearson, J.M. ve Odom, M.D. (2008). Profiling Cyber-Slackers in the Workplace: Demographic, Cultural, and Workplace Factors', Journal of Internet Commerce, 6 (3): $75-89$.

Vitak, J., Crouse, J. ve LaRose, R. (2011). Personal Internet Use at Work: Understanding Cyberslacking, Computers in $\mathrm{Hu}$ man Behavior, 27: 1751-1759.

Zoghbi, P. (2009). Inequity, Conflict, and Compliance Dilemma as Causes of Cyberloafing, International Journal of Conflict Management, 20 (2): 188-201.

Zoghbi, P., Tacoronte, D.V. ve Ding, J.T. (2006). Do Current Anti-Cyberlaofing Disciplinary Practices Have a Replica in Research Findings? A Study of The Effects of Coercive Strategies on Workplace Internet Misuse, Internet Research, 16 (4): 450-46. 